\title{
Bull's political vision: past, present and future
}

Article

Accepted Version

Humphreys, A. (2020) Bull's political vision: past, present and future. Cambridge Review of International Affairs, 33 (4). pp. 471-473. ISSN 1474-449X doi:

https://doi.org/10.1080/09557571.2020.1785120 Available at https://centaur.reading.ac.uk/91201/

It is advisable to refer to the publisher's version if you intend to cite from the work. See Guidance on citing.

To link to this article DOI: http://dx.doi.org/10.1080/09557571.2020.1785120

Publisher: Taylor \& Francis

All outputs in CentAUR are protected by Intellectual Property Rights law, including copyright law. Copyright and IPR is retained by the creators or other copyright holders. Terms and conditions for use of this material are defined in the End User Agreement.

\section{www.reading.ac.uk/centaur}

\section{CentAUR}

Central Archive at the University of Reading

Reading's research outputs online 


\section{Bull's Political Vision - Past, Present and Future}

Adam R. C. Humphreys (University of Reading)

The thought of the English School, and especially of Hedley Bull, on whose work this essay focuses, has often been regarded as somewhat conservative. Bull famously prioritised order over justice, offered a state-centric analysis of world politics focusing on 'international society', and favoured a 'classical' approach within IR theory (see Bull 1966; 2002); this reflected his underlying 'middleground ethics' (Cochran 2009).

Recent work within the English School has tended to retain Bull's focus on the structure and functioning of international society (see, for example, Knudsen and Navari 2019). However, a recent reconsideration of Bull's seminal text, The Anarchical Society (2002), identifies a latent flexibility in his thinking which he did not himself fully exploit, but which has the potential to illuminate broader aspects of contemporary world politics (Suganami et al 2017). In order to see this, it is necessary to recognize how closely Bull's analysis was tied to (his reading of) the historical context in which he was writing (see Suganami et al 2017: 305-21).

As is well known, The Anarchical Society is 'an inquiry into the nature of order in world politics' (Bull 2002: xxxii); in addressing this issue it provides what Bull calls 'an implicit defence of the states system, and more particularly of ... international society' (2002: 307). What is less often noticed is that Bull's judgement that a study of order in world politics should concentrate on international society involves a sharp restriction in focus for which he provides a historically-specific justification.

Bull explicitly recognized that the 'study of world politics should be concerned with the global political process as a whole' and hence cannot be limited to 'interstate politics' - as he points out, there is a 'wider world political system of which the states system is only part' (2002: 266-7). He judged, however, that, although order in world politics may 'one day' take a different form, at the time he was writing such order as existed was provided by international society (2002: 22). Moreover, his immediate concern was that the Cold War, the end of empire, and the expansion of international society beyond its European origins had made this order 'precarious' (2002: 248). Bull's view, in short, was that given its prospective decline, a study of order in world politics must, at the time he was writing, focus on international society. He therefore asked what role its primary institutions played 'in the special circumstances of the present time' (2002: 122; see also 97, 156, $178,194)$. While he concluded that the immediate 'prospects ... for order in world politics lie in attempts to arrest ... [the] decline' of international society, he also acknowledged that 'such a conclusion stands in need of continual re-assessment' (2002: 307-8). 
If Bull's focus on international society is therefore a more contingent feature of his thought than is often supposed, his preoccupation with the challenges it faced also constrained him from fully exploiting the breadth of his own conceptual framework. As Barry Buzan points out, Bull failed fully to develop the concept of 'world society' (2001: 477). However, in considering how Bull's approach might be applicable to contemporary world politics, it is also worth recalling his acknowledgement that both international society and world society are situated in relation to a broader 'world political system', that is, 'the world-wide network of interaction that embraces not only states but also other political actors, both "above" the state and "below" it' (Bull 2002: 266). Bull recognized, even in the 1970s, that 'business enterprises, trade unions, political parties, professional associations, churches, all have their being partly within the transnational nexus that bypasses ... state-to-state relations' (2002: 267). However, he saw nothing new in this; he doubted whether 'transnational relationships ... at present play a more important role, relatively to the relationships of states, than in earlier phases of the wider political system in which they both figure' (2002: 268).

Whether or not this judgement was correct, Bull certainly under-estimated how rapidly the transnational dimension of world politics would develop. This is especially obvious in the global economy, where, as Louis Pauly argues, the management of systemic risk occurs through transnational regulatory frameworks involving both states and private, market actors (Suganami et al 2017: 179-97, 309). Similarly, Robert Falkner argues that the global climate regime has become increasingly trans-nationalized, as sub-national political authorities, businesses, and NGOs take the initiative in setting climate norms, developing low-carbon strategies, and establishing governance mechanisms (Suganami et al 2017: 198-215, 309). Such developments reveal the importance of the 'world political system' within Bull's conceptual scheme, for whereas he associated 'world society' with the emergence of a cosmopolitan consensus, the 'world political system' accommodates forms of 'global interdependence' that may not express such a consensus (Bull 2002: 278).

Identifying the sources of order within world politics is as important now as it was in Bull's day. In order to develop this project as fully as possible, it will be helpful to recognize the extent to which Bull's analysis was shaped by contingent and contextual judgements. Acknowledging the residual historicism within his political vision (see Bevir and Hall forthcoming) can help to draw out the hitherto under-appreciated flexibility within his conceptual scheme and that of the English School more broadly. Exploiting this flexibility permits a broader range of questions to be asked than those which are typically conceived of as defining the English School. In addition to questions about the changing constitution of the 'world political system' and the effects thereof, these might also include more interpretive questions about changing perceptions, within an evolving world political system, of both international and world society. For example, Katarzyna Kaczmarska asks how widely the 
idea of 'international society' is accepted within contemporary world politics and hence how adequate it is as a basis for understanding a world political system that is no longer dominated by the West (see Suganami et al 2017: 270-85).

Posing such questions takes us beyond Bull's own context-bound focus on 'international society', and even beyond subsequent work on 'world society', yet remains faithful to the underlying project of which both are part. As such, it provides a promising way forwards for the English School.

\section{References}

Bevir, Mark and Ian Hall. Forthcoming. The English School and the Classical Approach: Between Modernism and Interpretivism. Journal of International Political Theory.

Bull, Hedley. 1966. International Theory: The Case for a Classical Approach. World Politics 18(3): 36177.

Bull, Hedley. 2002. The Anarchical Society: A Study of Order in World Politics, $3^{\text {rd }}$ ed. Basingstoke: Palgrave.

Buzan, Barry. 2001. The English School: An Underexploited Resource in IR. Review of International Studies 27(3): 471-88.

Cochran, Molly. 2009. Charting the Ethics of the English School: What "Good" is There in a MiddleGround Ethics? International Studies Quarterly 53(1): 203-25.

Knudsen, Tonny Brems and Cornelia Navari (eds.). 2019. International Organization in the Anarchical Society: The Institutional Structure of World Order. Basingstoke: Palgrave.

Suganami, Hidemi, Madeline Carr, and Adam Humphreys (eds.). 2017. The Anarchical Society At 40: Contemporary Challenges and Prospects. Oxford: Oxford University Press. 